\title{
Assessing forest health via linking the geochemical properties of a soil profile with the biochemical parameters of vegetation
}

\author{
V. Kopačková $\cdot$ Z. Lhotáková $\cdot$ F. Oulehle $\cdot$ \\ J. Albrechtová
}

Received: 2 January 2013/Revised: 12 September 2013/Accepted: 22 April 2014/Published online: 6 May 2014

(C) Islamic Azad University (IAU) 2014

\begin{abstract}
The transfer of chemical elements/compounds within the soil-plant chain is a part of the biochemical cycling, and this system is controlled by biotic and abiotic factors which determine the final mobility and availability of chemical variables. Heavy metal contamination and low $\mathrm{pH}$ are stress factors that lead to changes in the contents of important foliage compounds, which can be used as nonspecific indicators of plant stress. In this study, Norway spruce forests in the Sokolov region, being a part of the "Black Triangle," were selected to assess geochemical and biochemical interactions in the natural soil/plant system. The authors studied the relationship between soil and spruce needle contents of macronutrients and potentially toxic elements and tested whether the soil parameters and their vertical distribution within a soil profile (two organic and two mineral horizons) affect foliage biochemical parameters (contents of photosynthetic pigments, phenolic compounds and lignin). Factor analysis was used to identify underlying variables that explained the pattern of
\end{abstract}

Electronic supplementary material The online version of this article (doi:10.1007/s13762-014-0602-3) contains supplementary material, which is available to authorized users.

V. Kopačková $(\bowtie) \cdot$ F. Oulehle

Czech Geological Survey, Klárov 3, 11821 Prague 1,

Czech Republic

e-mail: veronika.kopackova@seznam.cz

V. Kopačková

Department of Applied Geoinformatics and Cartography,

Faculty of Science, Charles University in Prague, Albertov 6,

12843 Prague 2, Czech Republic

Z. Lhotáková · J. Albrechtová

Department of Experimental Plant Biology, Faculty of Science, Charles University in Prague, Viničná 5, 12843 Prague 2, Czech Republic correlations within and between the biochemical and geochemical datasets. Aluminum (Al) and arsenic (As) were identified as toxic elements with high bio-availability for spruce trees, and both were taken up by trees and translocated to the foliage. The correlations between two toxic element contents in needles ( $\mathrm{Al}$ and $\mathrm{As}$ ) and the contents of soluble phenolic compounds and total carotenoid to chlorophyll ratio suggest that these latter two biochemical parameters, which both proved to be sensitive to the soil geochemical conditions, can serve as suitable non-specific stress markers.

Keywords Norway spruce (Picea abies L. Karst) health . Non-specific stress markers · Heavy metal stress · Factor analysis · Phenolic compounds · Photosynthetic pigments

\section{Introduction}

The transfer of trace elements within the soil-plant continuum is a part of the biogeochemical cycling of chemical elements. Plant species vary in their ability to withstand exposure to heavy metals from hyperaccumulation known for phytoextraction species to prevention of uptake characteristic for phytostabilization species (Salt et al. 1998; Nwoko 2010; Mani et al. 2012a, b). Heavy metal contamination and other negative physio-chemical changes under soil conditions, such as low $\mathrm{pH}$, are often a consequence of long-term industrial pollution (Lepedus et al. 2005; Tuzhilkina 2009).

Changes in the contents of important plant compounds can be used as non-specific indicators of plant stress; these include the contents of photosynthetic pigments, phenolic compounds and lignin, as shown for coniferous trees by many authors (e.g., Soukupová et al. 2000; Lepedus et al. 
2005; Tzvetkova and Hadjiivanova 2006). Additionally, these parameters can be monitored by the means of hyperspectral (HS) remote sensing and enable large-scale monitoring of forest health (Campbell et al. 2004; Mišurec et al. 2012; Kupková et al. 2012).

Limited work has been performed under field conditions exploring the effects of accumulated sediment/soilborne metals on biochemical processes in plant tissues and assessment of their suitability as potential biomarkers of metal stress (MacFarlane 2002; Bialonska et al. 2007). Additionally, the contents of available macronutrients $\left(\mathrm{Ca}^{2+}, \mathrm{Mg}^{2+}, \mathrm{K}^{+}\right)$can also play an essential role in the tree physiology. Therefore, there is an urgent need for the development of methodologies for assessing the sublethal effects of trace elements in conjunction with macronutrient availability and the way in which these soil characteristics affect leaf biochemical parameters in situ.

The biochemical composition of spruce needles with their longevity and exposure to environmental conditions is often used as a bio-indicator of soil or air contamination (Ollerová et al. 2010; Tuzhilkina 2009). Particularly, the contents of photosynthetic pigments are closely related to photosynthetic performance and can serve as early-warning symptoms of plant stress, before macroscopic changes are detected (e.g., Lepedus et al. 2005; Soukupová et al. 2000). The chlorophyll content of needles generally decreases under stress conditions, including nutrient deficiency and the presence of heavy metals (Huang and Tao 2004; Ivanov et al. 2011; Maestri et al. 2010). In general, conifers allocate relatively high ratios (7.3-12.3\%) of the whole-tree carbon to foliar phenolics (Aspinwall et al. 2011). Phenolic compounds represent a very heterogeneous group playing a role in defense mechanisms against pathogenes and herbivores (Klepzig et al. 1996) and environmental stress conditions, often serving as a non-specific stress marker. Tannins are involved in chelating heavy metals in plant cells (Lavid et al. 2001); in addition, polyphenols such as tannins not only inhibit decay of soil organic matter, but they may also impede soil $\mathrm{N}$ mineralization-immobilization reactions (Northup et al. 1998; Yu et al. 2003). Lignin is a structural compound of polyphenolic nature, and its content in foliage plays an important role in litter decomposition and nutrient cycling (Ushio et al. 2009). Thus, changing the content of phenolics in litter may alter wider biogeochemical carbon cycling in forest soils.

In this study, Norway spruce forests in the Sokolov region, the north-western part of the Czech Republic, were selected to assess geochemical and biochemical interactions in the natural soil/plant system. This region is exceptional for its long-term excessive lignite mining history and was also greatly affected by air pollution and soil acidification during the second half of the twentieth century (Moldán and Schnoor 1992). Even today, this part of the country with its open-pit lignite mining is considered to be one of the most polluted regions in the Czech Republic. Norway spruce (Picea abies L. Karst) is a dominant species in the silviculturally managed coniferous forests in Central Europe and particularly in the Czech Republic. However, this tree species has proven to be prone to environmental stresses. Long-term industrial pollution resulted in largescale spruce forest dieback observed in many regions of Central Europe, particularly in the area of the so-called Black Triangle (Moldán and Schnoor 1992), the well know region in Europe heavily polluted in the second half of the twentieth century. Therefore, monitoring of the health condition of spruce forests remains important for forest management in Central Europe. Particularly, the response of tree species to adverse soil conditions (e.g., contents of trace elements, basic cations depletion, and acidification) is of great importance.

The authors analyzed a wide range of biochemical parameters in the Norway spruce needles serving as nonspecific stress markers (biochemical dataset): photosynthetic pigments, soluble phenolic compounds, lignin and water content. Furthermore, around the sampled trees, the contents of selected macronutrients, which are present in the form of exchangeable cations $\left(\mathrm{Ca}^{2+}, \mathrm{Mg}^{2+}\right.$, $\mathrm{K}^{+}$) and $\mathrm{Al}$ as well as selected heavy metals (e.g., Zn, $\mathrm{Cu}$, As and $\mathrm{Hg}$ ), were determined in the corresponding soil profiles (geochemical dataset). In addition to basic statistics, factor analysis was used to identify underlying variables or factors that explain the pattern of correlations within and between the biochemical and geochemical sets of the variables described above. Factor analysis was previously successfully employed using environmental data and was particularly tested for the purposes of mineral exploration (Harraz et al. 2012) and to interpret diverse geochemical datasets (Tripathi 1979; Ijmker et al. 2012) as well as water or soil chemical data (Fitzpatrick et al. 2007). The authors assume that this method is also well suited to studying relationships and chemical/biochemical interactions in the soil/plant system and, to their knowledge, has not yet been used for this purpose.

As the present study quantitatively correlates a wide range of spruce needle biochemical parameters with macronutrient and accumulated heavy metal contents determined for four soil horizons in the polluted region, the aims have been to:

- Determine macronutrient/heavy metal abundances and their associations present in four different soil horizons (including organic and mineral soil horizons) and investigate whether these associations and their vertical distribution within a soil profile affect the accumulation of the same chemical elements in foliage. 
- Based on the determined soil and soil-plant relationships, define a conceptual model which will bring new insights into soil-plant uptakes and stress reactions at the sites.

- Assess the applicability of using selected needle biochemical parameters (photosynthetic pigment contents, phenolic and lignin contents, and selected nutritional and trace element contents) as biological indicators of adverse soil conditions (low $\mathrm{pH}$, high concentrations of trace elements) in Norway spruce forest ecosystems.

This work was carried out at the Czech Geological Survey and at the Faculty of Science (Charles University in Prague) within 2009-2011.
Fig. 1 Scheme showing the topography and simplified geological situation of the studied area
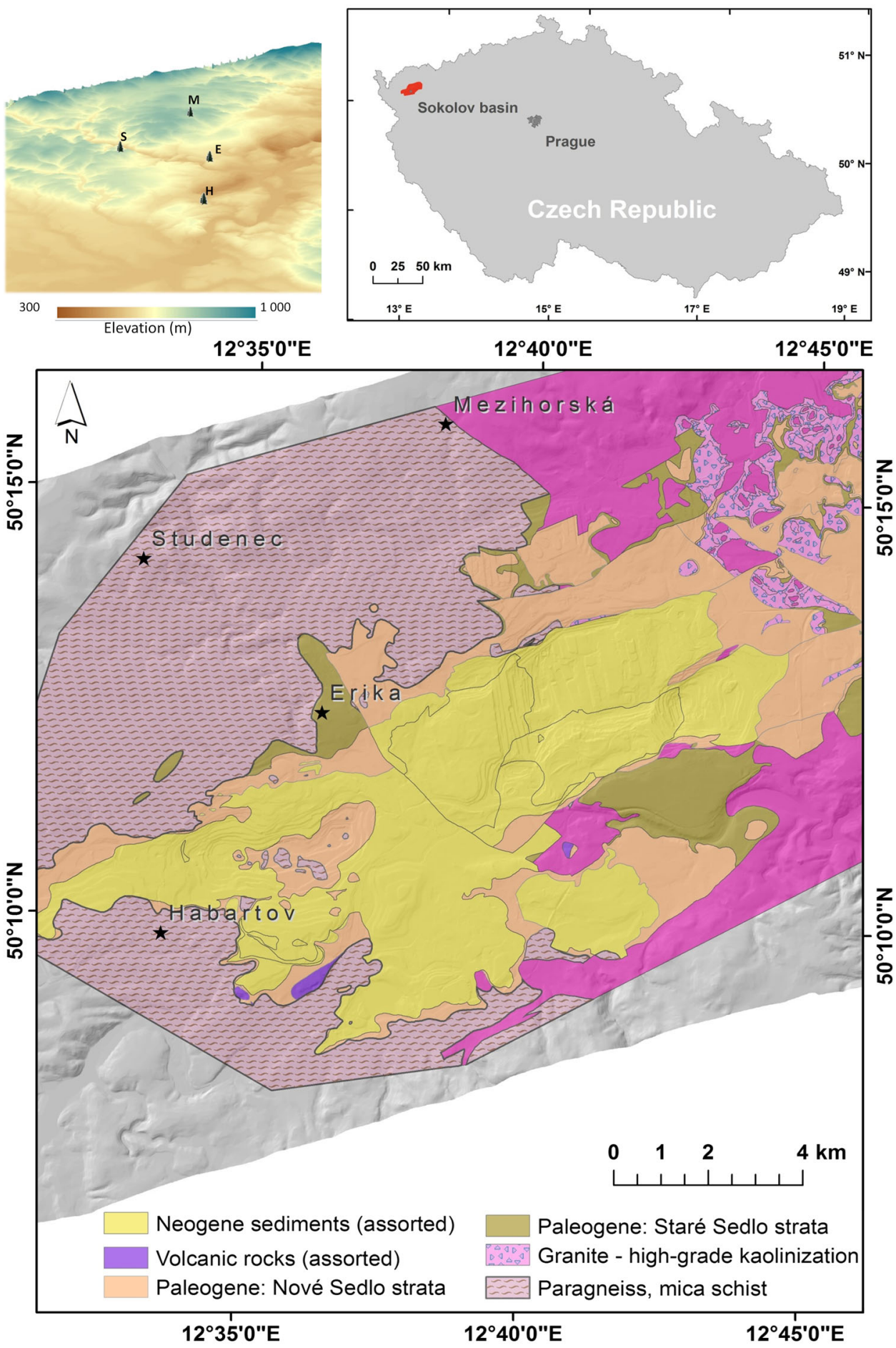
Table 1 Norway spruce test sites (forest age based on the records of the Forest Management Institute, http://www.uhul.cz/en/zz/)

\begin{tabular}{lllllll}
\hline Site & $\begin{array}{l}\text { Latitude } \\
(\mathrm{N})\end{array}$ & $\begin{array}{l}\text { Longitude } \\
(\mathrm{E})\end{array}$ & $\begin{array}{l}\text { Elevation } \\
(\mathrm{m} \text { a.s.1. })\end{array}$ & $\begin{array}{l}\text { Forest age } \\
(\text { years })\end{array}$ & $\begin{array}{l}\text { Distance from the } \\
\text { open-pit mines }(\mathrm{km})\end{array}$ & Geological unit \\
\hline Erika & $50^{\circ} 12^{\prime} 25^{\prime \prime}$ & $12^{\circ} 36^{\prime} 17^{\prime \prime}$ & 495 & $40-60$ & 6.4 & Staré Sedlo sandstones \\
Habartov & $50^{\circ} 09^{\prime} 48^{\prime \prime}$ & $12^{\circ} 33^{\prime} 28^{\prime \prime}$ & 477 & $40-60$ & 11.2 & Paragneiss, mica schist \\
Mezihorská & $50^{\circ} 15^{\prime} 50^{\prime \prime}$ & $12^{\circ} 38^{\prime} 17^{\prime \prime}$ & 678 & $60-80$ & 5.8 & Paragneiss, mica schist \\
Studenec & $50^{\circ} 14^{\prime} 09^{\prime \prime}$ & $12^{\circ} 33^{\prime} 00^{\prime \prime}$ & 722 & $40-60$ & 8.5 & Paragneiss, mica schist \\
\hline
\end{tabular}

\section{Materials and methods}

\section{Test site}

The study was performed in the Sokolov basin in the western part of the Czech Republic, in a region affected by long-term extensive lignite mining (Fig. 1). Due to the mining activities and coal burning power plants that were built in the immediate vicinity of the mined area, this region is one of the most contaminated areas of the Czech Republic where high abundances of trace elements have been detected (Fabiánek 2004). The average altitude of the study region is about $470 \mathrm{~m}$. Because the basin is surrounded by the Krušné Hory Mountains, precipitation is above the average for the Czech Republic and the local climate in the region is subject to more extreme weather, characterized by colder and wetter conditions. According to the data of the meteorological station situated nearby (Karlovy Vary, $606 \mathrm{~m}$ a.s.1.), long-term (1962-2006) annual temperature and precipitation were $6.7^{\circ} \mathrm{C}$ and $589 \mathrm{~mm}$, respectively.

The Sokolov basin in the Czech Republic is composed of rocks of Oligocene to Miocene age and is $8-9 \mathrm{~km}$ wide and up to $36 \mathrm{~km}$ long, with a total area of about $200 \mathrm{~km}^{2}$. The basement of the Sokolov Basin is formed of Variscan and pre-Variscan metamorphic complexes of the Eger, Erzgebirge, Slavkov Forest, Thuring-Vogtland Crystalline Units, and granitoids of the Karlovy Vary Pluton (Fig. 1). The basal late Eocene Staré-Sedlo-Formation is formed of well-sorted fluvial sandstones and conglomerates and is overlain by a volcano-sedimentary complex up to $350 \mathrm{~m}$ thick, which contains three lignite seams (Rojík 2004). The brown coal (lignite) contains 5-8 \% sulfur (S) and belongs among coal seams enriched in As (Simon and Hally 1984; Yudovich and Ketris 2005) and other heavy metals, such as $\mathrm{Cd}, \mathrm{Ni}, \mathrm{Cu}, \mathrm{Zn}, \mathrm{Pb}$ (Bouška and Pešek 1999). Due to the presence of $\mathrm{S}$ in the coal, the lignite mines, both still active and abandoned, are largely affected by acid mine drainage (AMD) (Kopacková et al. 2011, 2012).

The selected natural forest stands surround the lignite open-pit mines in Sokolov, but have not been directly affected by the mining activities. However, the soil in all of the stands exhibits low $\mathrm{pH}$ and higher contents of some heavy metals (As, $\mathrm{Hg}$ ). Norway spruce was selected as it represents the predominant forest species in this region; in addition, spruce needles were confirmed to be well suited for detection of contamination (Suchara et al. 2011). The authors selected four research sites dominated by mature Norway spruce forests (natural forest sites) of similar age (Table 1); this was important criteria as the stand age is the most important factor for defoliation (Zirlewagen et al. 2007). The stands were located at a maximum distance of $12 \mathrm{~km}$ from the active lignite open-pit mines (Fig. 1; Table 1). None of the selected sites exhibited any severe symptoms of macroscopic damage, and they were all classified as damage class 1 with total crown defoliation not exceeding $25 \%$ and average needle retention of $8-10$ needle age classes.

\section{Soil samples}

In each forest stand, five representative sampling pits were chosen to collect soil samples. Material was collected from four soil horizons (two organic and two mineral). The sampled horizons have the following characteristics: horizon 1-organic horizon $(\mathrm{Ol}+\mathrm{Of})$; horizon 2-organic horizon (Oa); horizon 3-mineral soil $0-10 \mathrm{~cm}$, mixed with humus, usually darkened (A0-10); horizon 4-mineral soil $10-20 \mathrm{~cm}$ (A10-20). The total depth of mineral soil $(20 \mathrm{~cm})$ was chosen to reflect the majority of tree root distribution. The collected material was dried in the air prior to sieving. Exchangeable cations and selected trace elements were determined in all four horizons. Exchangeable cations $\left(\mathrm{Ca}^{2+}, \mathrm{Mg}^{2+}, \mathrm{K}^{+}\right)$and $\mathrm{Al}$ were analyzed in $0.1 \mathrm{M} \mathrm{BaCl}_{2}$-extracts by the atomic absorption spectrophotometry (AAS, Perkin-Elmer AAnalyst 100). To measure selected trace elements $(\mathrm{Cu}, \mathrm{Zn}, \mathrm{As}, \mathrm{Hg})$, samples were sieved $(<5 \mathrm{~mm}$ for $\mathrm{Ol}$, Of and $\mathrm{Oa}$; and $<2 \mathrm{~mm}$ for mineral soil) and homogenized using a portable Innov-x Alpha RFA spectrometer.

Furthermore, for the first two horizons, the $\mathrm{pH}$, total exchangeable acidity (TEA) and total $\mathrm{C}$ and $\mathrm{N}$ were measured. Taking in account the character of the parent lithologies together with the fact that $\mathrm{C}$ was analyzed only for two organic horizons, the total $\mathrm{C}$ can be entirely related to organic carbon (Corg). Soil $\mathrm{pH}$ was determined in 
distilled water and in $1 \mathrm{M} \mathrm{KCl}$. To measure TEA, $\mathrm{BaCl}_{2^{-}}$ extracts were titrated by $0.025 \mathrm{M} \mathrm{NaOH}$ to $\mathrm{pH}=7.8$. Total $\mathrm{C}$ and $\mathrm{N}$ were determined simultaneously using a Carlo-Erba Fisons 1108 analyzer.

The overall statistics of the soil properties are presented in Supplementary material: Table 1. Each of the datasets contains measured variables of soil geochemical properties at four various depths within the soil profiles.

\section{Norway spruce samples}

At each of the four test sites, 10-15 representative trees were selected. A tree-climber cut branches from the production part of the crown, which means that all the sampled branches were sunlit and contributed significantly to the photosynthetic production of the tree. One branch was sampled in the upper level of the production part (U) of the crown almost at the boundary with the most upper juvenile part of the crown and the second branch in the lower level of the production crown part (L). Needles of the first (1) and third year (3) were sampled from each branch for subsequent chemical and biochemical analyses.

Photosynthetic pigments (chlorophyll $a$ and $b$ : Cab, total carotenoids: Car) were extracted in dimethyl formamide according to (Porra et al. 1989) and determined spectrophotometrically based on equations from (Wellburn 1994). Soluble phenolic compounds were determined according to (Singleton 1965). Frozen needles were homogenized in liquid nitrogen. Phenolics (FFW $=$ fresh weight, FDW $=$ dry weight) were extracted in $80 \%$ methanol (v/ v) in a water bath $\left(50{ }^{\circ} \mathrm{C}\right)$, and the concentrations were determined spectrophotometrically at a wavelength of $750 \mathrm{~nm}$ using a Helios $\alpha$ spectrophotometer (Unicam, Cambridge, UK) with Folin-Ciocalteau phenol reagent and gallic acid as a standard (for details see Soukupová et al. 2000). The lignin ( $\mathrm{Lig}$ ) content was determined by thioglycolate solubilization according to (Lange et al. 1995), and the amount of lignin was determined spectrophotometrically at a wavelength of $280 \mathrm{~nm}$ using hydrolytic lignin [Aldrich Chemical Company, USA; (8672-93-3)] as a standard.

Analyses of $\mathrm{Ca}, \mathrm{K}, \mathrm{Mg}, \mathrm{Al}, \mathrm{Cu}, \mathrm{Zn}, \mathrm{As}$ and $\mathrm{Hg}$ were performed for the first-year needles sampled from the lower production part of the crown (L1). Needle samples were slowly combusted $\left(550{ }^{\circ} \mathrm{C}\right)$ and then digested in concentrated $\mathrm{HF}(40 \%$, p.a., $15 \mathrm{ml})$ and $\mathrm{HClO}_{4}(70 \%$, p.a., $2 \mathrm{ml}$ ) on a hot plate. The following evaporation residue was digested in $5 \mathrm{ml}$ of $\mathrm{HCl}(37 \%$, p.a.). Distilled water was used to make a $100 \mathrm{ml}$ solution which was used for cations measurements at AAS (Perkin-Elmer AAnalyst 100). $\mathrm{Hg}$ was determined by AAS after pyrolysis of the samples, and As was analyzed using hydride generation of arsenic species coupled with atomic absorption (HGAAS).
The overall statistics of the needle properties were further statistically assessed and are presented in Supplementary material: Tabs 3 and 5 .

\section{Statistical methods}

First, the Shapiro-Wilk test (1965) was employed to test the normal distribution of both the geochemical and biochemical datasets, and some of the variables were not normally distributed according to this test (Supplementary material: Tabs 1 and 5). However, since the ratios between the maximum and minimum measurement concentrations are generally high enough, log-transformation was employed to squeeze/stretch the values on the logarithmic (loge) scale with the exception of the $\mathrm{pH}$, as this parameter is already log-transformed and exhibits normal distribution. After this transformation, distributions with skewnesses varied between -0.8 and 0.8 , or with kurtosis between -3 and 3 for all of the geochemical and most of the biochemical parameters. Such datasets more or less behave like normally distributed (Ijmker et al. 2012). However, the water content at both levels (L1, L3) and $\mathrm{Hg}$ content at level L1 did not fulfill this condition, and this fact was taken into consideration when interpreting the results. Further statistics was applied to the log-transformed data.

As the Norway Spruce needle samples were collected from two different crown positions (U-upper, L-lower) and needle ages (1-3 years old), analysis of the variance (twoway ANOVA) was employed to test whether there are statistically significant differences in the biochemical properties of the Norway Spruce needles with regard to their position within a crown and their age. Only the needle age significantly influenced all the examined biochemical characteristics (Supplementary material: Table 4) and was considered in further statistical assessments (PCA and factor analysis).

The relationships between (1) the geochemical parameters within the four soil horizons, (2) the biochemical parameters (photosynthetic pigment contents, phenolic and lignin contents) conducted for two different needle ages (1-3 years old) from position L and (3) biochemical parameters including selected nutritional and trace element content of the sampled trees (first-year needles, lower position: L1) were assessed using the Pearson correlation coefficient. The bivariate correlation was attained at a $95 \%$ confidence level (2-tailed). As a great number of soil parameters were assessed, the Pearson correlation coefficients were transformed into the form of color-coded correlation matrix (Figs. 2, 5, 6) for easer interpretation.

Afterward, factor analysis was employed. on the sets of variables that represented (1) chemical variables uncounted for each soil horizon, (2) the common chemical variables determined for both soil horizons and the tree needles 
(macronutrients and selected heavy metals) and (3) biochemical variables determined for the Norway spruce needles (macronutrients and selected heavy metals). Factor analysis of the soil parameters enabled study of the correlations between elements, forming groups with similar behavior (natural associations) in each horizon and of how these associations change with soil depth (Supplementary material: Tabs. 8 and 9; Fig. 2). The approach comparing the abundances of the common chemical variables, which were determined for all the four soil horizons as well as for the tree needle samples, enabled the authors to study which chemical elements present in the soil have been taken up by the vegetation and thus have the most significant impact on the vegetation health and physiological functions (Supplementary material: Tabs. 10 and 11; Fig. 4). Finally, factor analysis of the biochemical parameters allowed determination of the correlating biochemical parameters that can affect specific physiological functions of the trees (Supplementary material: Tabs. 12 and 13).

Factor analysis was performed by the SPSS program (version 14.0). Principle component analysis was used to extract the factors and to form uncorrelated linear combinations of the observed variables. An orthogonal rotation method (varimax), which is the most common orthogonal rotation criterion (Davis 2002), was employed to rotate the factors. The varimax rotation fits the axes to the maximum direction of variance, thereby spreading the explained variance more evenly over the different factors (Hartmann and Wunnemann 2009). This rotation method minimized the number of variables that have high loadings on each factor and in that way simplified the interpretation of the factors. New data were derived from these linear combinations, forming the principal components (PC), which can be displayed as scores and weights. There can be an infinite number of new factors; however, the first PCs, or factors, account for the greatest variability in the data (Webster 2001). Factor loadings are correlation coefficients between the original variables and factors and are intended to investigate the processes that control data variability. A loading on one variable close to \pm 1 indicates a strong correlation between the variable and the factor. The authors considered the variables that exhibited a loading of $>0.4$ or $<-0.4$ to be statistically significant.

\section{Results and discussion}

Geochemical properties and their changes across the soil profile

The $\mathrm{pH}$ of the sampled soils was low (2.96-3.65) with a slight increase toward deeper mineral soils (Supplementary material: Table 1). According to Kabata-Pendias (2004) several trace metals (especially $\mathrm{Cd}, \mathrm{Zn}, \mathrm{Co}, \mathrm{Cu}$ and $\mathrm{Ni}$ ) are readily mobile in such acid soils, which are generally characterized by oxidizing conditions, and are available to plants. In addition, low $\mathrm{pH}$ is also a serious problem as it facilitates the release of aluminum ( $\mathrm{Al}$ ) from $\mathrm{Al}$-containing minerals into the soil solution forming toxic conditions for forest vegetation or downstream aquatic organisms (Krám et al. 2009). In particular, it is a matter of concern that soil acidification caused by acid deposition, together with the consequent depletion of labile pools of nutrient cations (e.g., $\mathrm{Ca}^{2+}, \mathrm{Mg}^{2+}$ ) and enhancing leaching of $\mathrm{Al}$ from the soil, could contribute to forest dieback (Driscoll et al. 2001; Juice et al. 2006). To assess the possible negative effect of aluminum on base cation uptake (Hruška and Krám 1994), the molar ratio of $\mathrm{Ca} / \mathrm{Al}$ concentrations were calculated (Supplementary material: Tabs 2). Only in the most top horizon $(\mathrm{Ol}+\mathrm{Of})$ the $\mathrm{Ca} / \mathrm{Al}$ ratios exceeded the critical value $=1$, previously reported to be the threshold for damage to plant roots (Matzner and Prenzel 1992).

For each soil horizon, the concentration ranges (min., max.), mean values and standard deviations are shown in Supplementary material: Table 1 . As regards the exchangeable cations, $\mathrm{Ca}$ was the most abundant cation in all four horizons, followed by $\mathrm{Al}, \mathrm{K}, \mathrm{Mg}$. Comparing the total concentrations of trace elements, $\mathrm{Zn}$ was the most abundant metal, followed by $\mathrm{Cu}$, As and $\mathrm{Hg}$. The basic statistics also show that elements such as $\mathrm{Mg}, \mathrm{Ca}, \mathrm{K}$ and $\mathrm{As}$ are present in significantly higher concentrations in the topmost horizon $(\mathrm{Ol}+\mathrm{Of})$ and that their abundances decrease with increasing soil depth. Therefore, they are most probably delivered to the soil as litter fall. On the other hand, the abundances of $\mathrm{Zn}$ increase with increasing soil depth and this indicates that this element is most probably of lithological origin. Elements such as $\mathrm{Al}, \mathrm{Cu}$ and $\mathrm{Hg}$ exhibit the highest abundances in the second humus-rich horizon (Oa) and point to strong binding of these elements to the soil organic matter (Blaser et al. 2000; Mani and Kumar 2005).

The measured concentrations of exchangeable cations and trace elements were compared with the mean values classified and published for the Czech Republic (Fabiánek 2004) and in general, the cation concentrations were found to correspond to low values on the scale for the Czech Republic. Considering the $\mathrm{C} / \mathrm{N}$ ratio, there are no significant differences between the two organic horizons. The average $\mathrm{C} / \mathrm{N}$ ratio in the studied forest stands ranged between 24.9 and 35.0 in $\mathrm{Ol}+\mathrm{Of}$ and between 21.8 and 34.4 in Oa.

In terms of the trace element gradients, the organic horizons contained moderate amounts of $\mathrm{Cu}(50$ and $79 \mathrm{mg} / \mathrm{kg}$, respectively) and $\mathrm{Zn}(103$ and $89 \mathrm{mg} / \mathrm{kg})$. In both organic horizons and in A0-10 the contents of As exceeded the limit value given by the regulations issued by 


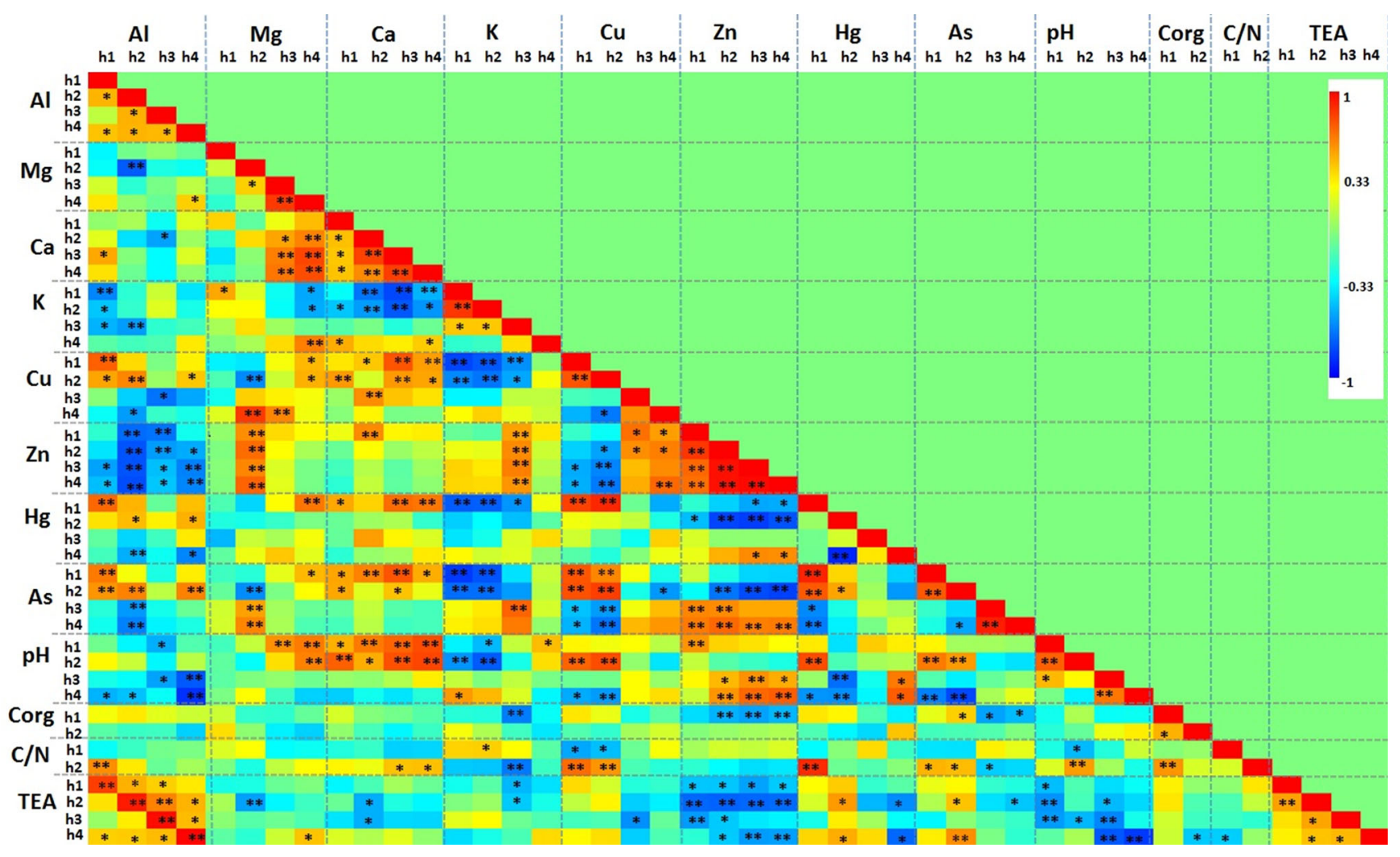

Fig. 2 Pearson correlation color-coded matrix (the values were loge transformed): soil profile geochemical properties; the coefficients were assigned colors according to their values [color scale from dark

the Ministry of the Environment of the Czech Republic. Additionally, high contents of $\mathrm{Hg}$ were detected across the whole soil profile (max in Oa: $1.63 \mathrm{mg} / \mathrm{kg}$ ).

Analysis of the color-coded matrix (Fig. 1) reflects strong positive correlations across the entire soil profiles for $\mathrm{Zn}$, indicating that this element is of lithological origin. This corresponds to the results published by Borůvka et al. (2005) as they found that most topsoil and subsoil Zn was bound in silicates. Naturally, significant positive correlations for all four horizons exist for $\mathrm{Mg}-\mathrm{Ca}$ as a result of organic material decomposition. On the other hand, a generally significant negative correlation exists between Zn-TEA.

Further statements are formulated, interpreting together both the results of the correlation matrix and also the results of factor analysis (Fig. 1; Supplementary material: Tabs 8 and 9), as the factor analysis allows identifying relationships that are not readily evident from simple correlation analysis.

\section{Horizon 1 (Ol + Of)}

Factor 1 accounts for $42 \%$ of the data variability. There are two associations of this factor: $\mathrm{Al}-\mathrm{As}-\mathrm{Hg}-\mathrm{Cu}$ (high positive loadings above 0.750 ) representing mainly toxic blue $($ correlation $=-1)$ to dark red $($ correlation $=1)]$. **Correlation is significant at the 0.01 level, *correlation is significant at the 0.05 level

elements, and the correlation between $\mathrm{Ca}$ and the $\mathrm{pH}$ (positive loadings around 0.460). Factor 2 accounts for $22 \%$ of the data variability and, in this case, a strong relationship was found between $\mathrm{Zn}$ and $\mathrm{pH}$ as well as between Al-TEA-Corg. The affinity of organic matter for Al indicates that, in this surface horizon, organic acids deliver the hydrogen ions and bind $\mathrm{Al}^{3+}$; if the $\mathrm{pH}$ is below $4.5, \mathrm{Al}^{3+}$ can be considered to be a trivalent "base cation" equivalent to $\mathrm{Mg}^{2+}$ and $\mathrm{Ca}^{2+}$ (Clarholm and Skyllberg 2013). Factor number 3 covered about $19 \%$ of the data variability and correlation between the $\mathrm{C} / \mathrm{N}$ and $\mathrm{Mg}-\mathrm{Ca}$ association was identified, corresponding to parameters that have their origin in the organic material and related decomposition processes.

\section{Horizon 2 (Oa)}

Factor 1 accounts for $44 \%$ of the data variability. One main association, $\mathrm{Ca}-\mathrm{Cu}-\mathrm{As}$, characterizes this factor and correlates with the $\mathrm{C} / \mathrm{N}$ ratio and the $\mathrm{pH}$. Surprisingly, $\mathrm{Ca}$ fell into this group, this indicates that $\mathrm{Ca}$ originates mainly from the decomposition of organic material coming from the litter in this horizon. The affinity of $\mathrm{Cu}$ and As for soil organic matter and the stability of organic complexes were demonstrated by Berthelsen et al. (1994) and by Yudovich 

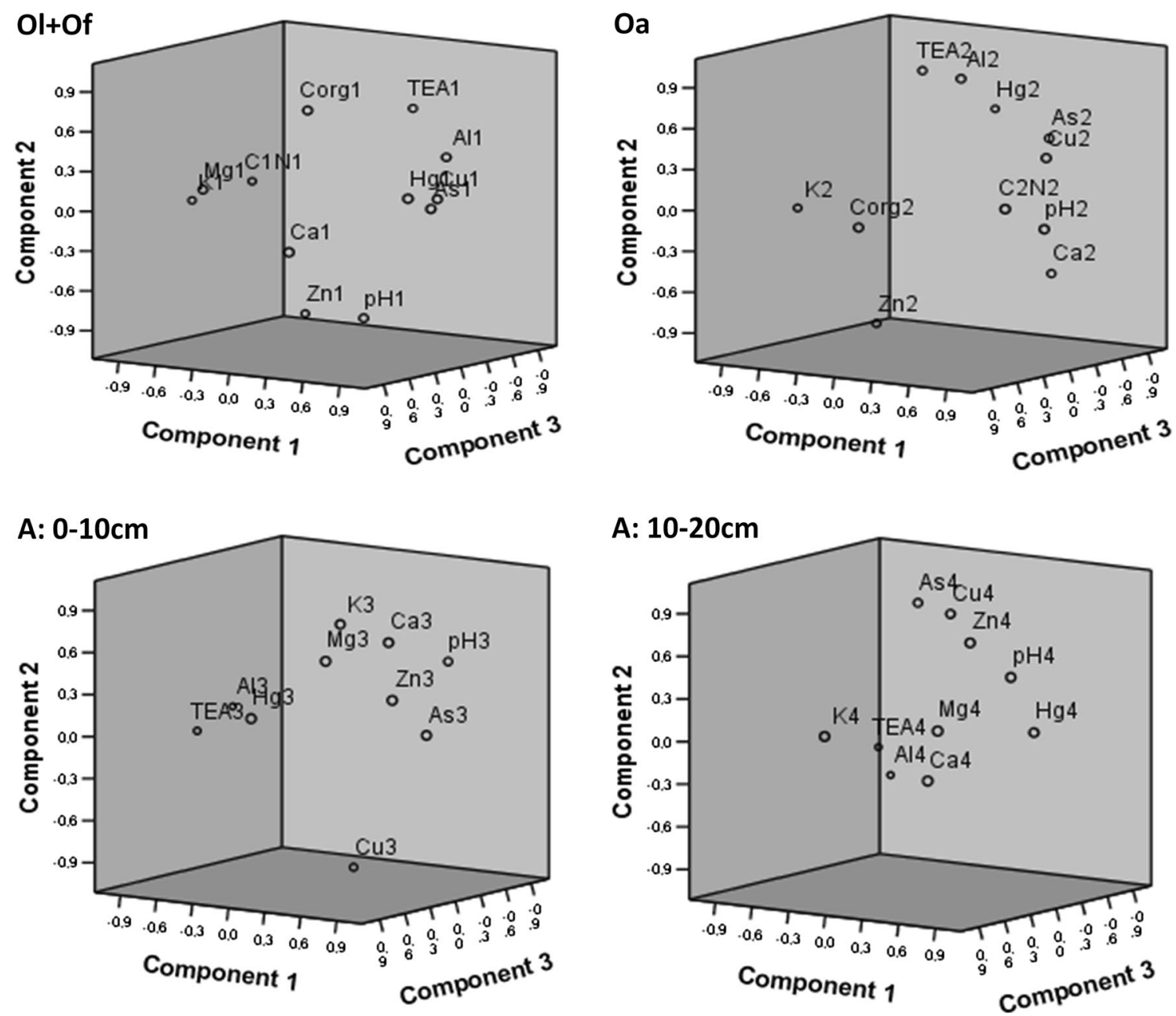

Fig. 3 Factor analysis: 3D plot of the first three components calculated for the four different horizons

and Ketris (2005), respectively. However, as $\mathrm{Cu}$ and $\mathrm{As}$ correlate with $\mathrm{C} / \mathrm{N}$, but not with the organic matter content (Corg) by itself; thus, most likely these elements in this horizon originate mainly from poorly decomposed organic material, which is typically characterized by a high $\mathrm{C} / \mathrm{N}$ ratio (Egli et al. 2010). Two major associations were identified in factor 2 (27\% of the data variability), a group of mainly toxic elements (Al- $\mathrm{Hg}-\mathrm{As}-\mathrm{Cu}$ ) correlating with TEA and the $\mathrm{Mg}-\mathrm{Ca}-\mathrm{Zn}$ association. $\mathrm{Ca}$ and $\mathrm{Mg}$ correspond to nutrients and $\mathrm{Zn}$ is also an essential element if not present in high concentrations (Pallardy 2008). Factor 3 ( $9 \%$ of the data variability) is explained mainly by the variability in $\mathrm{Hg}$ (high positive loadings) and Corg (high negative loadings).

\section{Horizon 3 (A0-10)}

Factor 1 accounts for $65 \%$ of the data variability and two major groups were found; the $\mathrm{Mg}-\mathrm{Ca}-\mathrm{K}$ and $\mathrm{Zn}-\mathrm{As}$ associations, which have a strong relationship with the soil $\mathrm{pH}$.
The authors assume that both associations are products of the weathering of diverse minerals (e.g., aluminosilicates, feldspars, biotite). On the other hand, factor 2 (22\% of the data variability) indicated a relationship between $\mathrm{Mg}-\mathrm{Ca}-$ $\mathrm{K}$, nutrient association that most likely has organic origin.

Horizon 4 (O10-20)

The lithology of the parent rock material affects this horizon more when the overlying horizons described above, in this profile the mineral products of weathering, have common occurrence. Factor 1 accounts for $61 \%$ of the data variability and one major group- $\mathrm{Mg}-\mathrm{Ca}-\mathrm{Zn}$ and $\mathrm{Hg}$ - correlating with the $\mathrm{pH}$ - explains this factor. The major $\mathrm{Zn}-\mathrm{Cu}-\mathrm{As}$ associations was identified in factor 2 (19\% of the data variability) and, also in this group, correlated with the $\mathrm{pH}$. The relationship between $\mathrm{Mg}-\mathrm{Ca}-\mathrm{K}$ was identified in factor 3 (12\% of the data variability), the same nutrient association detected in the overlying horizon A0-10. 


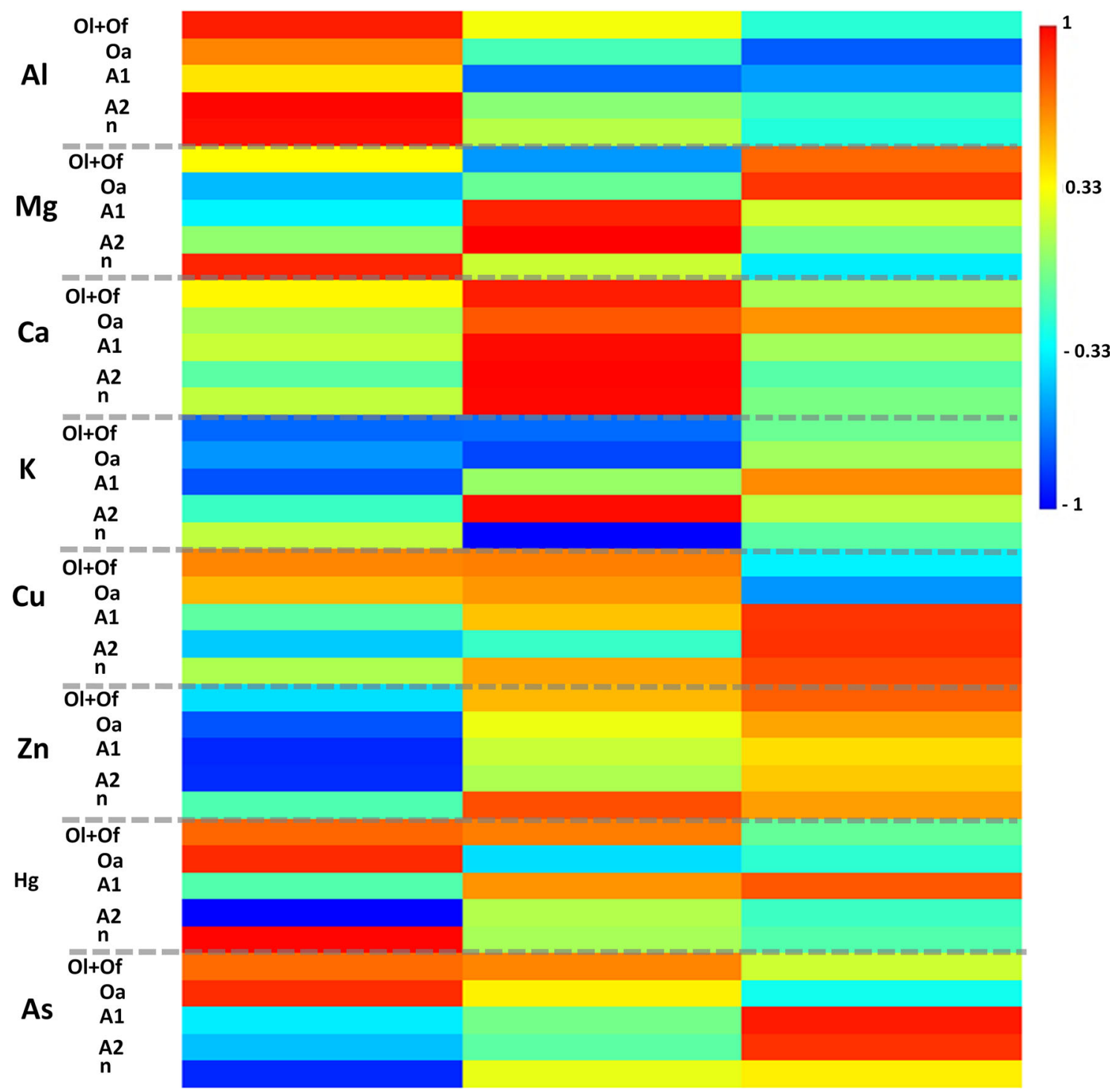

Fig. 4 Color-coded matrix of the loading factors for the first free components (column numbering follows the PC order, e.g., column 1 is $\mathrm{PC} 1)$ : element abundances in the soil horizons $(\mathrm{Ol}+\mathrm{Of}, \ldots$,
A10-20) and the Norway spruce needles (marked as $n$ ), all the values were $\log _{e}$ transformed

Principle component 1 (49\% of the data variability) indicated relationships between soil and needle element contents for Al, Hg and As (Fig. 3; Supplementary material: Tabs 10 and 11): (1) the amounts of $\mathrm{Al}$ in needles correlated positively with the soil contents in all four soil horizons, (2) $\mathrm{Hg}$ in the needles had a strong correlation with $\mathrm{Hg}$ abundances in the two organic horizons, although it needs to be taken in account that $\mathrm{Hg}$ in the sampled needles did not exhibit normal distribution and optimally this result should be further tested using a new dataset. However, to support the relationship, a similar distribution of $\mathrm{Hg}$ in the soil profile and foliage was also described by Obrist et al. (2012) in Douglas fir and red alder stands, (3) the As content in the needles correlated with the As 


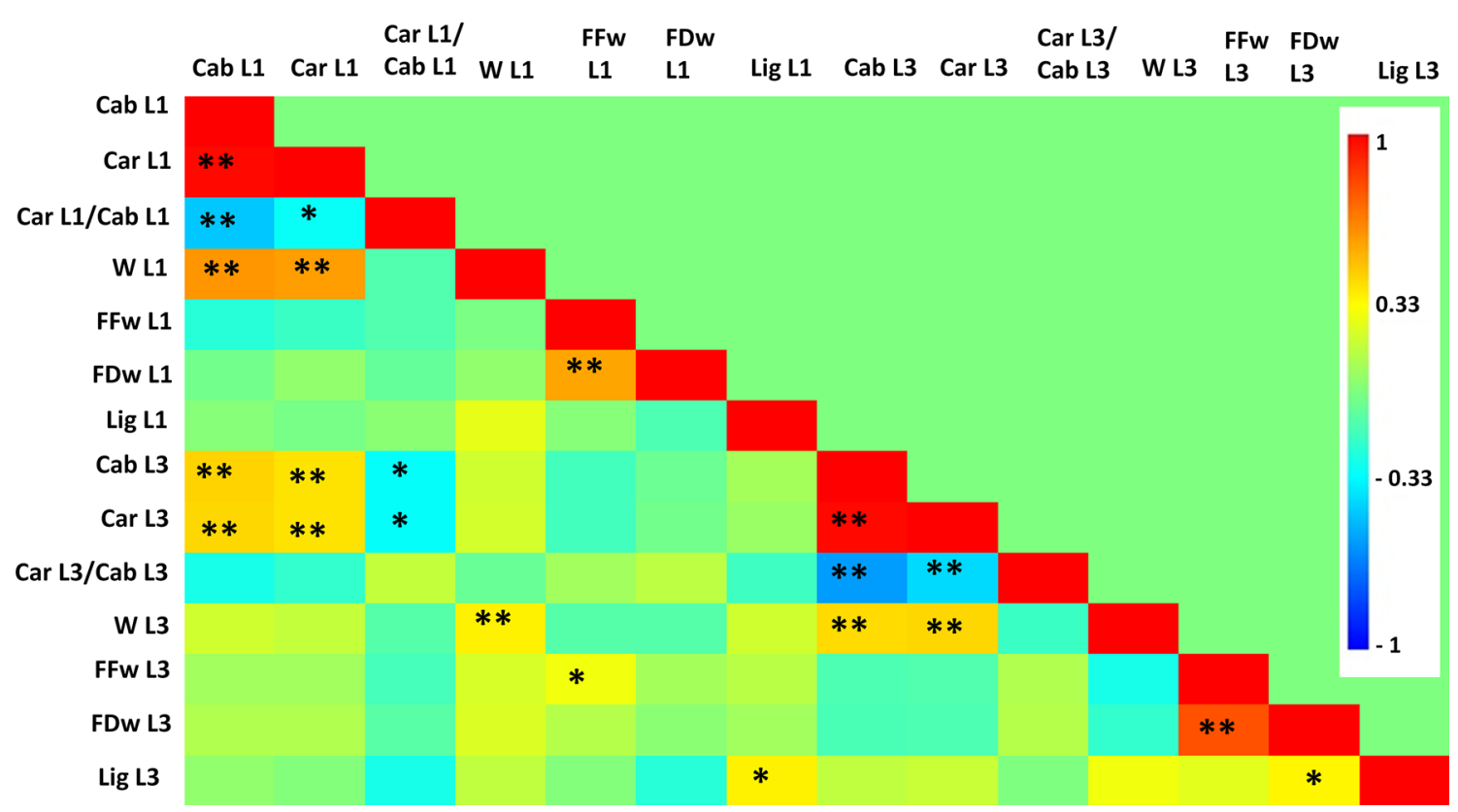

Fig. 5 Pearson correlation color-coded matrix (the values were $\log _{e}$ transformed): chemical and biochemical properties of the Norway at the positions of L1 and L3, the coefficients were assigned colors

according to their values [color scale from dark blue (correlation $=$ -1 ) to dark red (correlation $=1$ )]. $* *$ Correlation is significant at the 0.01 level, *correlation is significant at the 0.05 level

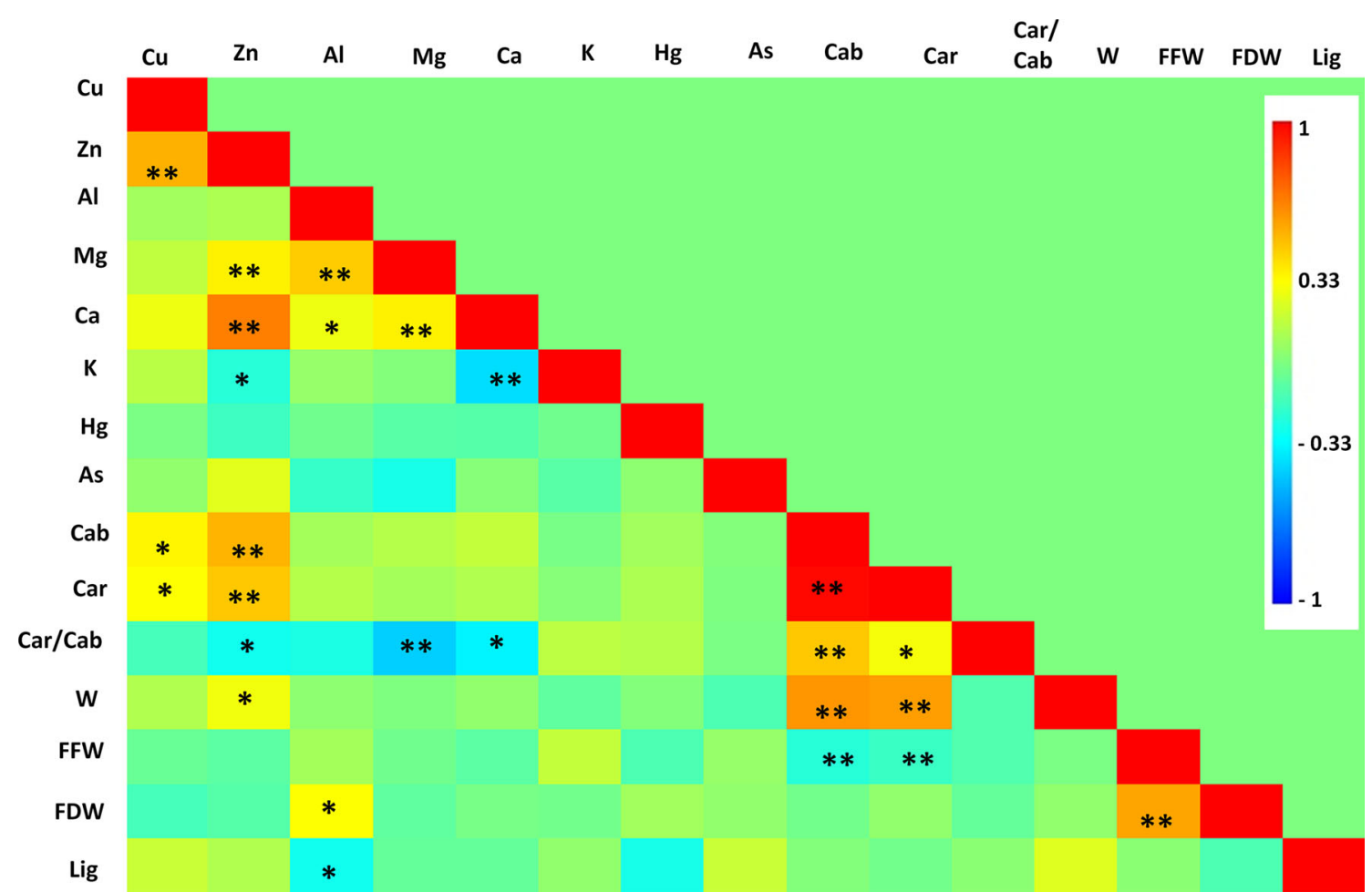

Fig. 6 Pearson correlation color-coded matrix (values were $\log _{e}$ transformed): chemical and biochemical properties of the Norway Spruce at the position of L1, the coefficients were assigned colors according to their values [color scale from dark blue (correlation $=$ -1 ) to dark red (correlation $=1$ )]. **Correlation is significant at the 0.01 level, *correlation is significant at the 0.05 level 


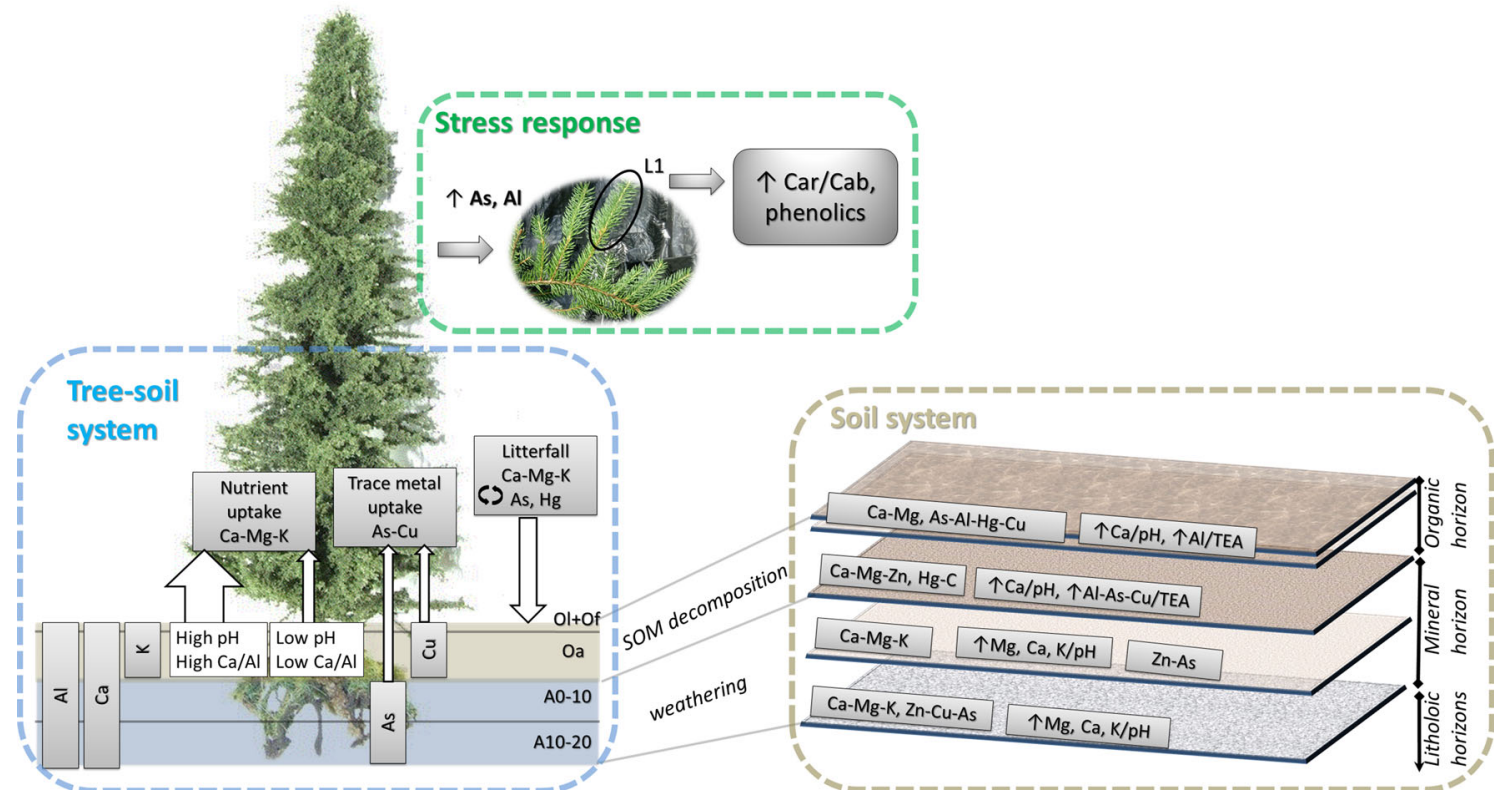

Fig. 7 Conceptual overview of the chemical and biochemical processes taking place in the studied soil-tree system

contents in A0-10 and A10-20, the mineral horizons already influenced by the parent rock material. This was in accordance with findings that roots take up As mainly in inorganic forms (arsenate and arsenite) and As is transported to the above-ground organs in the form of arsenite (Zhao et al. 2010). Similarly, a study of the spatial distribution of trace elements in Norway spruce stands showed that As is mainly associated with the mineral horizons in Norway spruce forest soil (Brun et al. 2010).

Principle component 2 (39\% of the data variability) identified the following relationships (Fig. 3; Supplementary material: Tabs 10 and 11): (1) Ca: correlations between the needle contents and the abundances in all four soil horizons. This correlation is in accordance with the fact that trees take up $\mathrm{Ca}$ from all the depths of their rooting volume (Dijkstra and Smits 2002) and, if present, they take up $\mathrm{Ca}$ in amounts that significantly excess their physiological needs. The Ca concentration in the first-year needles at the end of the growing season can vary by more than $100 \%$ among years (Clarholm and Skyllberg 2013) and depends on the $\mathrm{Ca}$ availability in the soil and water transport from the soil to the foliage via the transpiration stream. (2) $\mathrm{K}$ : the abundances in needles correlate with the abundances in the first two organic horizons, as $\mathrm{K}$ is enriched in the forest floor horizons through the decomposition of litter. During the decomposition of organic matter (OM) monovalent ions are released relatively quickly and are thus available for uptake by trees. The high turnover rate of $\mathrm{K}$ between the forest floor and foliage is thus responsible for the close relationship, (3) $\mathrm{Zn}$ : correlation between the needle content and the $\mathrm{Zn}$ content in the first soil horizon was detected, this indicate a litter fall origin, (4) $\mathrm{Cu}$ : a relationship was found between the needle content and the $\mathrm{Cu}$ abundances in the $\mathrm{Ol}+\mathrm{Of}$, Oa and A1-10 soil horizons. This result demonstrates that, in acid soils, the $\mathrm{Cu}$ content is more often related to organic matter pools (Egli et al. 2010). In addition, component 3 (12\% of the data variability) allowed identification of a relationship between the needle abundances of $\mathrm{Cu}$ and mainly the lower mineral horizons (A0-10 and A10-20).

Variability of biochemical parameters according to the needle position in a crown and the age

In general, the mean pigment contents of the sampled trees (2.6 $\pm 0.8 \mathrm{mg} / \mathrm{g}$ DW of chlorophyll $a+b$ : Cab) correspond to healthy Norway spruce (Siefermannharms 1994). Assessing vertical gradients, only the contents of photosynthetic pigments and their ratio depended on the needle position within the production crown part, while the other biochemical parameters (soluble phenolics and water/lignin contents) were independent of the needle vertical position (Supplementary material: Tab. 4). In contrast, the needle age had a significant effect for all the investigated biochemical parameters. Therefore, the authors decided to keep the different needle age classes separated regardless of the needle vertical position in further statistical assessments.

The first and second components (31 and $18 \%$ of the data variability, respectively; Supplementary material: Tabs. 6 and 7) are explained mainly by the variances in the water (W), chlorophyll ( $\mathrm{Cab}$ ) and carotenoid (Car) contents 
in the L1 and L3 needles, respectively. The same relationship shows the correlation color-coded matrix (Fig. 4). A strong positive correlation between the contents of chlorophylls and carotenoids was expected, as both types of pigments cooperate in light harvesting in primary photosynthetic reactions (Demmig-Adams and Adams 1996). Although the first-year needles are assumed to be mature at the time of sampling (late July), the contents of Cab and Car in these needles usually increase in the subsequent one or two seasons (Albrechtova et al. 2008) and the water content decreases (Homolová et al. 2013), which may both change the strength of the relationships between these biochemical parameters and explain the stronger correlation between photosynthetic pigments and needle water contents in L1. Additionally, the Car/Cab ratio is influenced by needle age: in the first-year needles, the pigment ratio was more dependent on the carotenoid content in comparison with third-year needles, where the value of the $\mathrm{Car} / \mathrm{Cab}$ ratio was driven by increasing chlorophyll content (Fig. 4).

Component 3 ( $13 \%$ of the data variability) indicated a relationship between $\mathrm{Car} / \mathrm{Cab}$ ratio and soluble phenolic contents (both L1 position). In addition to the accessory light-harvesting function, carotenoids protect photosynthetic membranes and chlorophyll from reactive oxygen species (Pallardy 2008), and thus, the Car/Cab ratio may increase under oxidative stress caused by excessive light (Tausz et al. 2007) or heavy metal stress (Martinez-Penalver et al. 2012). Similarly phenolic compounds play a protective role due to their antioxidant properties (Bialonska et al. 2007). The synergic effect in scavenging reactive oxygen species may explain the positive loading of both the $\mathrm{Car} / \mathrm{Cab}$ ratio and soluble phenolics in component 3.

Component 4 (11\% of the data variability) as well as color-coded matrix (Fig. 4) identified the relationship between lignin and soluble phenolic compounds for the L3 position. Lignin and soluble phenolic compounds are both important protective secondary metabolites (Moura et al. 2010), although soluble phenolics are more connected with non-specific stress reactions and defense (being synthetized much faster after stressor effects), while lignin tends rather to play a structural role (less mobile).

\section{Chemical and biochemical properties of Norway spruce}

Although the Sokolov region is considered to be one of the most heavily contaminated in the country in terms of the wide range of metals, the studied trees did not exhibit either visible damage caused by metal contamination or high accumulation of trace elements in the needles (Supplementary material: Tabs. 3 and 5). The medians of $\mathrm{Ca}$, $\mathrm{Cu}, \mathrm{K}$ and $\mathrm{Hg}$ in the first-year spruce needles corresponded well with the values presented by Suchara et al. (2011), while the medians of $\mathrm{Mg}$ and $\mathrm{Zn}$ were higher. Assessing the contents of selected mineral elements $(\mathrm{Mg}, \mathrm{Ca}$ and $\mathrm{K})$, the first-year Norway spruce needles exhibited moderate values with no signs of deficiency (Fabiánek 2004). The critical loads of $\mathrm{Al}$ in plant tissues have not been generally established; however, the content of $\mathrm{Al}$ in needles in our study $(87 \mathrm{mg} / \mathrm{kg})$ was higher than that described by Suchara et al. (2011) and comparable with other studies on Norway spruce conducted in polluted areas, e.g., $30-120 \mathrm{mg} / \mathrm{kg} \mathrm{Al}$ (Jonard et al. 2012) and 30-200 mg/kg (Bussinow et al. 2008). The factor analysis (component number 4, Supplementary material: Tab. 13) as well as the correlation matrix (Fig. 6) shows that there are statistically significant positive correlations between $\mathrm{Zn}-\mathrm{Cu}$, which are both essential for many enzymatic functions, and similarly, both are required in very small quantities. The chlorophyll content exhibits a positive correlation with $\mathrm{Cu}$ and $\mathrm{Zn}$, which suggest that $\mathrm{Cu}$ and $\mathrm{Zn}$ do not play the role of contaminants here but are a suitable source of micronutrients. The next positive association was found between $\mathrm{Ca}-$ $\mathrm{Mg}-\mathrm{Al}$ and $\mathrm{Zn}-\mathrm{Ca}-\mathrm{Mg}$. Further statements are based on analyzing the results of both correlation matrix (Fig. 5) and factor analysis (Supplementary material: Tabs. 12 and 13). A significant negative linear relationship was found between $\mathrm{K}-\mathrm{Ca}$ and $\mathrm{K}-\mathrm{Zn}$. The latter negative relationships agree with the finding of Roivainen et al. (2012), who reported that the concentrations of soil macronutrients such as $\mathrm{K}, \mathrm{Mg}$ and $\mathrm{P}$ negatively affected the uptake of several trace elements ( $\mathrm{Co}, \mathrm{Mo}, \mathrm{Ni}, \mathrm{Pb}, \mathrm{U}$ and $\mathrm{Zn}$ ) in boreal forests.

The second component (13\% of the data variability) identified the relationship between the $\mathrm{K}$ content and phenolic compounds in the wet matter (both negative loadings) and between $\mathrm{Zn}-\mathrm{Al}$ (positive loadings). The components 3 (13\% of the data variability) and 4 (10\% of the data variability) identified the most sensitive biochemical parameters - phenolic compounds and $\mathrm{Car} / \mathrm{Cab}$ ratios-both were positively correlating with $\mathrm{As}$ and $\mathrm{Al}$, the elements considered to be toxic for coniferous forests (Zhao et al. 2010; Collignon et al. 2012).

\section{Conceptual model}

The obtained results discussed in the previous chapters allowed the authors to formulate a conceptual overview of the chemical and biochemical processes taking place in the studied soil-tree system (Fig. 7). The studied spruce sites are generally characterized by low $\mathrm{pH}$ and low $\mathrm{Ca} / \mathrm{Al}$, rather low concentrations of exchangeable cations, moderate concentrations of $\mathrm{Zn}$ and $\mathrm{Cu}$ and rather high contents of $\mathrm{Hg}$ and As. Using factor analysis, the authors were able to determine diverse nutrient/heavy metal associations that characterize the four studied horizons; among them, the 
$\mathrm{Al}-\mathrm{As}-\mathrm{Hg}-\mathrm{Cu}$ association of mainly toxic elements was identified in both organic horizons $(\mathrm{Ol}+\mathrm{Of}$ and $\mathrm{Oa})$ pointing to trace metal association with organic carbon and accumulation via litterfall. For two mineral horizons (A0-10 and A10-20), similar associations depending on the soil $\mathrm{pH}, \mathrm{Zn}-\mathrm{As}$ and $\mathrm{Zn}-\mathrm{As}-\mathrm{Cu}$ were identified. Considering the potentially toxic elements, the authors found correlations between soil and tree concentrations for $\mathrm{Al}$ (needle $\mathrm{Al}$ content correlated with the $\mathrm{Al}$ concentrations in all four horizons), As [needle As content correlated with the As concentrations in the mineral horizons $(\mathrm{A} 0-10$ and $\mathrm{A} 10-20)]$ and $\mathrm{Cu}$ in the organic horizons $(\mathrm{Ol}+\mathrm{Of}$ and Oa). The obtained results demonstrate that, in the studied low-pH soils, $\mathrm{Al}^{3+}$ behaves as a trivalent "base cation" and may be taken up by trees from all depths of their rooting volume. Similar to $\mathrm{Ca}$, the absolute contents of $\mathrm{Al}$ taken up from deep soil horizons increase in the topsoil when delivered as litter fall (Clarholm and Skyllberg 2013). The As contents in the needles correlate with the As contents in the mineral horizons, which are already influenced by the parent rock material; the authors assume that roots take up As mainly in inorganic form (Brun et al. 2010; Zhao et al. 2010). Affinity of the soil organic matter for $\mathrm{Hg}$ was identified, as reported by Kolka et al. (1999) or Mani and Kumar (2005). It is still not absolutely clear whether $\mathrm{Hg}$ is taken up by trees preferentially from the upper soil horizons and transported to the needles or whether it accumulates in the needles and surface soil profile from atmospheric deposition, as mentioned, e.g., by (Brun et al. 2010). Nevertheless, Hg accumulation in organic horizons supports the idea of litterfall-derived $\mathrm{Hg}$. $\mathrm{Hg}$ is reported to be immobile in soils (Adriano 2001); thus, the authors assume that $\mathrm{Hg}$ is loaded into the upper soil profile mainly by atmospheric deposition and via litter turnover. Two toxic elements, $\mathrm{Al}$ and As, were identified as mobile in the studied soils; additionally, a correlation was found between concentrations in the Norway spruce tissues (the first-year needles) and the two biochemical parameters-soluble phenolic compounds and $\mathrm{Car} / \mathrm{Cab}$ ratios.

\section{Conclusion}

Several statistical methods were utilized in this paper (e.g., color-coded correlation matrixes together with factor analysis) to explain the soil chemical and biochemical processes within the soil-tree system. Mature Norway spruce forests growing in acid soils (the mean $\mathrm{pH}$ varied between 3.0-3.7) formed the research subject. The presented statistical assessment led to the formulation of a conceptual model for the studied soil-tree system (Fig. 7).

In spite of the low $\mathrm{Ca} / \mathrm{Al}$ ratios, moderate contents of selected nutrients ( $\mathrm{Mg}, \mathrm{Ca}$ and $\mathrm{K}$ ) in the first-year needles are high enough, and the chlorophyll needle content proves that their availability in such acidified soils is still sufficient for Norway spruce, pointing out that the $\mathrm{Ca} / \mathrm{Al}$ ratio alone might be a weak predictor of the foliage nutrient status. High concentrations of $\mathrm{Al}$ in the first-year needles are in accordance with acid soil conditions that facilitate $\mathrm{Al}$ uptake by the roots.

Two toxic elements, $\mathrm{As}$ and $\mathrm{Al}$, were detected as mobile. Moreover, a correlation between concentrations in the Norway spruce tissues (the first-year needles) and the two biochemical parameters-soluble phenolic compounds and $\mathrm{Car} / \mathrm{Cab}$ ratios-was found. This finding shows that the production of phenolic compounds in the biomass could be stimulated and subsequently affect litter decomposition and overall soil carbon balance in regions with current or historic acidification and consequent mobilization of toxic elements (Al and As). Soluble phenolic compounds and the $\mathrm{Car} / \mathrm{Cab}$ ratio appeared to be the most sensitive biochemical parameters of all those assessed, and the authors suggest that they can serve as suitable nonspecific stress markers.

In general, the presented study contributes to better understanding of the relationships between soil and foliar chemistries, particularly, in coniferous forests affected by anthropogenic pollution.

Acknowledgments This research is being undertaken as part of a HYPSO scientific research project within the framework of Grant No. 205/09/1989 funded by the Czech Science Foundation. Many thanks are due to Dr. Petr Rojík (Sokolovská uhelná a.s.) for his substantial assistance with the field campaign, to all the students who participated in sample collection, and to Mgr. Drahomíra Bartáková who helped with biochemical assessments of phenolic compounds and lignin.

\section{References}

Adriano D (2001) Trace elements in terrestrial environmentsbiogeochemistry bioavailability and risks of metals. Springer, New York

Albrechtova J, Seidl Z, Aitkenhead-Peterson J, Lhotáková Z, Rock BN, Alexander JE et al (2008) Spectral analysis of coniferous foliage and possible links to soil chemistry: are spectral chlorophyll indices related to forest floor dissolved organic $\mathrm{C}$ and N? [Article; Proceedings Paper]. Sci Total Environ 404(2-3):424-432. doi:10.1016/j.scitotenv.2007.11.006

Aspinwall MJ, King JS, Booker FL, McKeand SE (2011) Genetic effects on total phenolics condensed tannins and non-structural carbohydrates in loblolly pine (Pinus taeda L.) needles. Tree Physiol 31(8):831-842. doi:10.1093/treephys/tpr073

Aznar JC, Richer-Lafleche M, Begin C, Begin Y (2009) Lead exclusion and copper translocation in black spruce needles. Water Air Soil Pollut 203(1-4):139-145. doi:10.1007/s11270009-9997-8

Berthelsen BO, Ardal L, Steinnes E, Abrahamsen G, Stuanes AO (1994) Mobility of heavy-metals in pine forest soils as influenced by experimental acidification. Water Air Soil Pollut 73(1-4): 29-48. doi:10.1007/bf00477974 
Bialonska D, Zobel AM, Kuras M, Tykarska T, Sawicka-Kapusta K (2007) Phenolic compounds and cell structure in bilberry leaves affected by emissions from a $\mathrm{Zn}-\mathrm{Pb}$ smelter. Water Air Soil Pollut 181(1-4):123-133. doi:10.1007/s11270-006-9284-x

Blaser P, Zimmermann S, Luster J, Shotyk W (2000) Critical examination of trace element enrichments and depletions in soils: $\mathrm{As} \mathrm{Cr} \mathrm{Cu} \mathrm{Ni} \mathrm{Pb}$ and $\mathrm{Zn}$ in Swiss forest soils. Sci Total Environ 249(1-3):257-280. doi:10.1016/s0048-9697(99)00522-7

Borůvka L, Vacek O, Jehlička J (2005) Principal component analysis as a tool to indicate the origin of potentially toxic elements in soils. Geoderma 128(3-4):289-300. doi:10.1016/j.geoderma. 2005.04.010

Bouška V, Pešek J (1999) Quality parameters of lignite of the North Bohemian Basin in the Czech Republic in comparison with the world average lignite. Int J Coal Geol 40(2-3):211-235. doi:10. 1016/s0166-5162(98)00070-6

Brun CB, Peltola P, Astrom ME, Johansson MB (2010) Spatial distribution of major trace and ultra trace elements in three Norway spruce (Picea abies) stands in boreal forests Forsmark Sweden. Geoderma 159(3-4):252-261. doi:10.1016/j.geoderma. 2010.07.018

Bussinow M, Sarapatka B, Dlapa P (2008) Effect of old mining activities on nutrient and toxic elements concentration in the biomass of Norway spruce (Picea abies L Karst.) and European Birch (Betula pendula L.). Int J Environ Pollut 33(2-3):235-247. doi:10.1504/ijep.2008.019396

Campbell PKE, Rock BN, Martin ME, Neefus CD, Irons JR, Middleton EM et al (2004) Detection of initial damage in Norway spruce canopies using hyperspectral airborne data. Int $\mathrm{J}$ Remote Sens 25(24):5557-5583. doi:10.1080/01431160410001 726058

Clarholm M, Skyllberg U (2013) Translocation of metals by trees and fungi regulates $\mathrm{pH}$, soil organic matter turnover and nitrogen availability in acidic forest soils. Soil Biol Biochem 63:142-153. doi:10.1016/j.soilbio.2013.03.019

Collignon C, Boudot JP, Turpault MP (2012) Time change of aluminium toxicity in the acid bulk soil and the rhizosphere in Norway spruce (Picea abies (L.) Karst.) and beech (Fagus sylvatica L.) stands. Plant Soil 357(1-2):259-274. doi:10.1007/ s11104-012-1154-2

Davis J (2002) Statistics and data analysis in geology, 3rd edn. Wiley, New York

Demmig-Adams B, Adams WW (1996) The role of xanthophyll cycle carotenoids in the protection of photosynthesis. Trends Plant Sci 1(1):21-26

Dijkstra FA, Smits MM (2002) Tree species effects on calcium cycling: the role of calcium uptake in deep soils. Ecosystems 5(4):385-398. doi:10.1007/s10021-001-0082-4

Driscoll CT, Lawrence GB, Bulger AJ, Butler TJ, Cronan CS, Eagar C, Lambert KF, Likens GE, Stoddard JL, Weathers KC (2001) Acidic deposition in the northeastern United States: sources and inputs ecosystem effects and management strategies. Bioscience 51(3):180-198. doi:10.1641/0006-3568(2001)051

Egli M, Sartori G, Mirabella A, Giaccai D, Favilli F, Scherrer D et al (2010) The influence of weathering and organic matter on heavy metals lability in silicatic Alpine soils. Sci Total Environ 408(4):931-946. doi:10.1016/j.scitotenv.2009.10.005

Fabiánek P (2004) Forest condition and monitoring in the Czech Republic 1984-2003, Ministry Of Agriculture of the Czech Republic and Forestry and Game Management Research Institute, ELAN spol. s.r.o., Přerov, Czech Republic

Fitzpatrick ML, Long DT, Pijanowski BC (2007) Exploring the effects of urban and agricultural land use on surface water chemistry across a regional watershed using multivariate statistics. Appl Geochem 22(8):1825-1840. doi:10.1016/j.apgeochem. 2007.03.047
Harraz HZ, Hamdy MM, El-Mamoney MH (2012) Multi-element association analysis of stream sediment geochemistry data for predicting gold deposits in Barramiya gold mine Eastern Desert Egypt. J Afr Earth Sci 68:1-14. doi:10.1016/j.jafrearsci.2012.03. 009

Hartmann K, Wunnemann B (2009) Hydrological changes and Holocene climate variations in NW China inferred from lake sediments of Juyanze palaeolake by factor analyses. Quatern Int 194:28-44. doi:10.1016/j.quaint.2007.06.037

Homolová L, Lukeš P, Malenovský Z, Lhotáková Z, Kaplan V, Hanuš J (2013) Measurement methods and variability assessment of the Norway spruce total leaf area: implications for remote sensing. Trees Struct Funct 27(1):111-121. doi:10.1007/s00468-0120774-8

Hruška J, Krám P (1994) Aluminum chemistry of the root-zone of forest soil affected by acid deposition at the lysina catchment Czech-Republic. Ecol Eng 3(1):5-16. doi:10.1016/0925-8574 (94)90007-8

Huang Y, Tao S (2004) Influences of excessive $\mathrm{Cu}$ on photosynthesis and growth in ectomycorrhizal Pinus sylvestris seedlings. J Environ Sci 16(3):414-419

Ijmker J, Stauch G, Hartmann K, Diekmann B, Dietze E, Opitz S et al (2012) Environmental conditions in the Donggi Cona lake catchment NE Tibetan Plateau based on factor analysis of geochemical data. J Asian Earth Sci 44:176-188. doi:10.1016/j. jseaes.2011.04.021

Ivanov YV, Savochkin YV, Kuznetsov VV (2011) Scots pine as a model plant for studying the mechanisms of conifers adaptation to heavy metal action: effects of continuous zinc presence on morphometric and physiological characteristics of developing pine seedlings. Russ J Plant Physiol 58(5):871-878. doi:10.1134/ s1021443711050104

Jonard M, Legout A, Nicolas M, Dambrine E, Nys C, Ulrich E et al (2012) Deterioration of Norway spruce vitality despite a sharp decline in acid deposition: a long-term integrated perspective. Glob Change Biol 18(2):711-725. doi:10.1111/j.1365-2486. 2011.02550.x

Juice SM, Fahey TJ, Siccama TG, Driscoll CT, Denny EG, Eagar C, Cleavitt NL, Minocha R, Richardson AD (2006) Response of sugar maple to calcium addition to northern hardwood forest. Ecology 87(5):1267-1280

Kabata-Pendias A (2004) Soil-plant transfer of trace elements-an environmental issue. Geoderma 122(2-4):143-149. doi:10.1016/ j.geoderma.2004.01.004

Klepzig KD, Smalley EB, Raffa KF (1996) Interactions of ecologically similar saprogenic fungi with healthy and abiotically stressed conifers. For Ecol Manag 86(1-3):163-169. doi:10. 1016/s0378-1127(96)03777-2

Kolka RK, Nater EA, Grigal DF, Verry ES (1999) Atmospheric inputs of mercury and organic carbon into a forested upland bog watershed. Water Air Soil Pollut 113(1-4):273-294. doi:10. 1023/a:1005020326683

Kopačková V, Chevrel S, Bourguignon A (2011) Spectroscopy as a tool for geochemical modeling. Proc SPIE 8181:818106. doi:10. 1117/12.898404

Kopačková V, Chevrel S, Bourguignon A, Rojík P (2012) Application of high altitude and ground-based spectroradiometry to mapping hazardous low-pH material derived from the Sokolov open-pit mine. J Maps 8(3):220-230. doi:10.1080/17445647.2012.705544

Krám P, Hruška J, Driscoll CT, Johnson CE, Oulehle F (2009) Longterm changes in aluminum fractions of drainage waters in two forest catchments with contrasting lithology. J Inorg Biochem 103(11):1465-1472. doi:10.1016/j.jinorgbio.2009.07.025

Kupková L, Potůčková M, Buřičová M, Kopačková V, Lhotáková Z, Albrechtová J et al (2012) Determination of lignin content in norway spruce foliage using nir spectroscopy and hyperspectral 
data. IEEE Int Geosci Remote Sens Symp (Igarss) 2012: 4190-4193

Lange BM, Lapierre C, Sandermann H (1995) Elicitor-induced spruce stress lignin—structural similarity to early developmental lignins. Plant Physiol 108(3):1277-1287

Lavid N, Schwartz A, Yarden O, Tel-Or E (2001) The involvement of polyphenols and peroxidase activities in heavy-metal accumulation by epidermal glands of the waterlily (Nymphaeaceae). Planta 212(3):323-331. doi:10.1007/s004250000400

Lepedus H, Viljevac M, Cesar V, Ljubesic N (2005) Functioning of the photosynthetic apparatus under low and high light conditions in chlorotic spruce needles as evaluated by in vivo chlorophyll fluorescence. Russ J Plant Physiol 52(2):165-170. doi:10.1007/ s11183-005-0024-7

MacFarlane GR (2002) Leaf biochemical parameters in Avicennia marina (Forsk.) Vierh as potential biomarkers of heavy metal stress in estuarine ecosystems. Mar Pollut Bull 44(3):244-256. doi:10.1016/s0025-326x(01)00255-7

Maestri E, Marmiroli M, Visioli G, Marmiroli N (2010) Metal tolerance and hyperaccumulation: costs and trade-offs between traits and environment. Environ Exp Bot 68(1):1-13. doi:10. 1016/j.envexpbot.2009.10.011

Mani D, Kumar C (2005) Study of the heavy metals mobility in different soils affecting vegetation. Natl Acad Sci Lett 28(7-8): $251-258$

Mani D, Sharma B, Kumar C, Pathak N, Balak S (2012a) Phytoremediation potential of Helianthus annuus $\mathrm{L}$ in sewageirrigated indo-gangetic alluvial soils. Int J Phytorem 14(3): 235-246. doi:10.1080/15226514.2010.498844

Mani D, Sharma B, Kumar C, Balak S (2012b) Depth-wise distribution mobility and naturally occurring glutathione based phytoaccumulation of cadmium and zinc in sewage-irrigated soil profiles. Int J Environ Sci Technol 1-14. doi:10.1007/s13762$012-0121-z$

Martinez-Penalver A, Grana E, Reigosa MJ, Sanchez-Moreiras AM (2012) The early response of Arabidopsis thaliana to cadmiumand copper-induced stress. Environ Exp Bot 78:1-9. doi:10. 1016/j.envexpbot.2011.12.017

Matzner E, Prenzel J (1992) Acid deposition in the german soiling area-effects on soil solution chemistry and al mobilization. Water Air Soil Pollut 61(3-4):221-234. doi:10.1007/bf00482606

Mišurec J, Kopačková V, Lhotáková Z, Hanuš J, Weyermann J, Entcheva-Campbell P et al (2012) Utilization of hyperspectral image optical indices to assess the Norway spruce forest health status. J Appl Remote Sens 6:063545. doi:10.1117/1.jrs.6.063545

Moldán B, Schnoor JL (1992) Czechoslovakia-examining a critically ill environment. Environ Sci Technol 26(1):14-21. doi:10. 1021/es00025a001

Moura JCMS, Bonine CAV, Viana JDF, Dornelas MC, Mazzafera P (2010) Abiotic and biotic stresses and changes in the lignin content and composition in plants. J Integr Plant Biol 52(4): 360-376

Northup RR, Dahlgren RA, McColl JG (1998) Polyphenols as regulators of plant-litter-soil interactions in northern California's pygmy forest: a positive feedback? Biogeochemistry 42(1-2):189-220. doi:10.1023/a:1005991908504

Nwoko CO (2010) Trends in phytoremediation of toxic elemental and organic pollutants. Afr J Biotechnol 9(37):6010-6016

Obrist D, Johnson DW, Edmonds RL (2012) Effects of vegetation type on mercury concentrations and pools in two adjacent coniferous and deciduous forests. J Plant Nutr Soil Sci 175(1): 68-77. doi:10.1002/jpln.201000415

Ollerová H, Marusková A, Kontrisová O, Pliestiková L (2010) Mercury accumulation in Picea abies (L.) Karst Needles with regard to needle age. Pol J Environ Stud 19(6):1401-1404

Pallardy S (2008) Physiology of woody plants. Elsevier, London
Porra RJ, Thompson WA, Kriedemann PE (1989) Determination of accurate extinction coefficients and simultaneous-equations for assaying chlorophyll-a and chlorophyll-b extracted with 4 different solvents-verification of the concentration of chlorophyll standards by atomic-absorption spectroscopy. Biochim Biophys Acta 975(3):384-394. doi:10.1016/s0005-2728(89)80347-0

Roivainen P, Makkonen S, Holopainen T, Juutilainen J (2012) Element interactions and soil properties affecting the soil-toplant transfer of six elements relevant to radioactive waste in boreal forest. Radiat Environ Biophys 51(1):69-78. doi:10.1007/ s00411-011-0393-6

Rojík P (2004) New stratigraphic subdivision of the tertiary in the Sokolov Basin in Northwestern Bohemia. J Czech Geol Soc 49(3-4):173-185

Salt DE, Smith RD, Raskin I (1998) Phytoremediation. Annu Rev Plant Physiol Plant Mol Biol 49:643-668

Shapiro SS, Wilk MB (1965) An analysis of variance test for normality (complete samples). Biometrika 52(3-4):591-611

Siefermannharms D (1994) Light and temperature control of seasondependent changes in the alpha-carotene and beta-carotene content of spruce needles. J Plant Physiol 143(4-5):488-494

Simon L, Hally J (1984) Rychlé stanovení arsenu v hnědém uhlí SHR-quick determination of arsenic in coal of the Northbohemian brown coal distrikt. Acta Montana 68:253-263

Singleton VL (1965) Colorimetry of total phenolics and phosphomolybdic-phosphotungstic acid reagents. In: Rossi VA (ed) Am J Enol Vitic 16:144-158

Soukupová J, Cvikrová M, Albrechtová J, Rock BN, Eder J (2000) Histochemical and biochemical approaches to the study of phenolic compounds and peroxidases in needles of Norway spruce (Picea abies). New Phytol 146(3):403-414. doi:10.1046/ j.1469-8137.2000.00666

Suchara I, Sucharová J, Holá M, Reimann C, Boyd R, Filzmoser P et al (2011) The performance of moss grass and 1- and 2-year old spruce needles as bioindicators of contamination: a comparative study at the scale of the Czech Republic. Sci Total Environ 409(11):2281-2297. doi:10.1016/j.scitotenv.2011.02.003

Tausz M, Landmesser H, Posch S, Monschein S, Grill D, Wienhaus O (2007) Multivariate patterns of antioxidative and photoprotective defence compounds in spruce needles at two central European forest sites of different elevation. Environ Monit Assess 128(1-3):75-82. doi:10.1007/s10661-006-9416-1

Tripathi VS (1979) Factor-analysis in geochemical-exploration. J Geochem Explor 11(3):263-275. doi:10.1016/0375-6742(79) 90004-9

Tuzhilkina VV (2009) Response of the pigment system of conifers to long-term industrial air pollution. Russ J Ecol 40(4):227-232. doi: $10.1134 / \mathrm{s} 1067413609040018$

Tzvetkova N, Hadjiivanova C (2006) Chemical composition and biochemical changes in needles of Scots pine (Pinus sylvestris L.) stands at different stages of decline in Bulgaria. Trees Struct Funct 20(4):405-409. doi:10.1007/s00468-006-0052-8

Ushio M, Miki T, Kitayama K (2009) Phenolic control of plant nitrogen acquisition through the inhibition of soil microbial decomposition processes: a plant-microbe competition model. Microb Environ 24(2):180-187. doi:10.1264/jsme2.ME09107

Webster R (2001) Statistics to support soil research and their presentation. Eur J Soil Sci 52(2):331-340. doi:10.1046/j.13652389.2001.00383.x

Wellburn AR (1994) The spectral determination of chlorophyll-a and chlorophyll-b as well as total carotenoids using various solvents with spectrophotometers of different resolution. J Plant Physiol 144(3):307-313

Yu ZS, Kraus TEC, Dahlgren RA, Horwath WR, Zasoski RJ (2003) Mineral and dissolved organic nitrogen dynamics along a soil acidity-fertility gradient. Soil Sci Soc Am J 67(3):878-888 
Yudovich YE, Ketris MP (2005) Arsenic in coal: a review. Int J Coal Geol 61(3-4):141-196. doi:10.1016/j.coal.2004.09.003

Zhao FJ, McGrath SP, Meharg AA (2010) Arsenic as a food chain contaminant: mechanisms of plant uptake and metabolism and mitigation strategies. Annu Rev Plant Biol 61:535-559
Zirlewagen D, Raben G, Weise M (2007) Zoning of forest health conditions based on a set of soil topographic and vegetation parameters. For Ecol Manag 248(1-2):43-55. doi:10.1016/j. foreco.2007.02.038 